Postprint - Finnane: ‘Controlling the alien’, published in Policing and Society19, no. 4, 2009: 442-467

\title{
CONTROLLING THE ‘ALIEN’ IN MID-TWENTIETH CENTURY AUSTRALIA: THE ORIGINS AND FATE OF A POLICING ROLE
}

\author{
Mark Finnane
}

\begin{abstract}
The capacity of police to manage immigrant populations in times of conflict was developed in the course of the twentieth century through a multiplicity of techniques and strategies. Inter-agency and cross-jurisdictional capability for the ends of population surveillance and crime control was historically contingent on institutional initiatives that are rarely explored. An important origin of such capability in Australia was the Conference of Police Commissioners, first held in 1903. Its agenda after the First World War was preoccupied with the management of aliens, the immigrant populations of Australia. This paper explores the institutional and political contexts that shaped the control of 'aliens' in Australia's early and mid-twentieth century with particular interest in the development of policing powers and techniques that operated within and without the crime control and prevention mandates that are most commonly associated with the modern public police. During these decades Australian police leaders, drawing on their own and international experience in two World Wars, expanded their vision of what policing of the alien demanded. By the early post-war years they sought universal surveillance of migrants through the still developing technologies of fingerprint and photographic databases. Their failure to achieve what they demanded at this time was a signal of their subordination in a politics of immigration that prioritised assimilation and integration of large new populations as a national undertaking.
\end{abstract}

Keywords: policing, immigration, police surveillance, aliens, police co-operation, history

* Mark Finnane is ARC Australian Professorial Fellow, ARC Centre of Excellence in Policing and Security, Griffith University, Brisbane, Australia. Email: m.finnane@griffith.edu.au. This paper draws from continuing research on the history of security and responses to violence in Australian history (ARC DP0771492). I am grateful to the Commissioners of Police in Australia for permission to consult the historical record of their annual conference; and to the National Archives of Australia for additional help. Thanks are due to John Myrtle, Canberra, for his invaluable research assistance; and to Clive Emsley, for facilitating access to the Association of Chief Police Officers Archives (Open University, Milton Keynes). 


\section{Introduction}

Controversy over the status and danger of outsiders has dominated the political landscape in Australia as in other Western countries in recent decades. Since 2001 three quite different episodes have accentuated the perceived threats, and elevated the politics of immigration and security to the centre stage of Australian politics. The infamous response of the Australian government (under Prime Minister John Howard) to the plight of refugees rescued by the Norwegian freighter Tampa in September 2001, together with its subsequent actions and negligence over the even more awful plight of the refugees on the vessel SievX (with the loss of more than 350 lives), highlighted the issues of refugee rights and diminished the standing of Australian immigration policy(Marr 2003)(Mares 2002). Revelations over the wrongful detention of Australian citizens Cornelia Rau and Vivian Solon (aka Alvares) as suspected 'unlawful non-citizens’ resulted in significant scrutiny of the administration and policing of Australia's immigration policies in 2002-3(Palmer 2005). In 2007 the arrest on national security grounds of an Indian doctor, Dr Mohamed Haneef, employed at Queensland's Gold Coast Hospital, his detention, release and then subsequent declaration by the Minister for Immigration as an unlawful non-citizen by virtue of the cancellation of his working visa, drew an extraordinary amount of attention (national and international) to the political and policy complex that brought together powers and practices of counter-terrorism, immigration and policing(Clarke 2008).

For some scholars such episodes constitute evidence of the continuing infamy of the Australian state and nation as entities characterised by a xenophobia with roots in the White Australia Policy and a determination to protect the privileges of a wealthy member of the Western alliance (see especially Burke 2007, Pickering 2006). A complementary literature connects these events to arguments about the contemporary state and its deployment of new powers and new technologies of control over those deemed dangerous to the state and nation (Pickering and Weber 2006). A developing field of critical security studies has been much preoccupied with what it sees as the very contemporary manifestations of a post-modern state which is simultaneously jealous of its own powers and privileges and all too ready to subject outsiders to the full weight of an exclusionary law. In extreme forms these critiques have seen in the plight of refugee camps a metaphor for contemporary existence. The overlapping of counter-terrorist policy with the development of more restrictive approaches to people mobility has encouraged the growth of critical treatments that see such contemporary phenomena as particularly new and insidious, or otherwise as continuous with the totalitarianism of Nazism in particular (Agamben 1998). The figure of the 'alien' is an exemplar in these critical sociological and philosophical accounts. In the words of Costas Douzinas, 'the alien is the gap 
between human and citizen' : 'Aliens are not citizens. They do not have rights because they are not part of the state and they are lesser human beings because they are not citizens.' (Douzinas 2007, 98-99)

This article approaches the question of the alien from a different perspective. It seeks to locate 'the alien' as a category with historical content, a status that was subject to constant change in political, legal and policing histories. ${ }^{1}$ In the first place it considers the degree to which the powers of contemporary states to police borders and exclude those who don't belong was shaped by the circumstances of war and peace as well as the institutional histories of modern government. Its focus on Australia, a modern nation-state whose constitutional foundation was closely linked with exclusionary and expulsionary politics (Fitzgerald 2007; Lake 2008) should not be taken as an excuse to regard the case as isolated. As will be noted, the politics of exclusion and population mobility control were of a part with the nineteenth and twentieth century state evolutionary contexts that shaped Australian possibilities. In that respect this study shares with other recent historical studies of policing a concern to contextualise the emergence of a contemporary politics of immigration and the nation state. The intensive administration of the immigrant populations of Paris in the inter-war years (Rosenberg 2006)(Thomas 2008), or of the American-Mexican border (Ngai 2004) share with the Australian story recounted here the early twentieth century expansion of a policing and bureaucratic framework that expressed something other than simply the politics of race and xenophobia.

Second, while the general framework of constitutional and legislative exclusion and control is well understood and much studied by historians, and more recently sociologists, the role within this history of police and policing is much less understood. Indeed the general indifference to the role of policing in histories of immigration and related fields must be regarded as in some ways symptomatic of a theoretical presumption about the role of police as automaton agents of a state whose policies and actions are always referred back to some other set of interests, eg of capital, or race. Correlatively, histories of intelligence agencies which ignore the articulation of intelligence and surveillance to other domestic governmental concerns run the risk of misunderstanding the context of population management of which intelligence was only one part. In the Australian context, for example, a significant research history of the country’s main intelligence agency is limited by the degree to which it places the agency at the core of government, rather than as one element of a larger governmental complex for the management of national security (McKnight 1994). Lack of contextual method informs other aspects of the historiography which has touched on the question of alien control with McKnight seeing the use of the term 'aliens' as 'a word which reveals much about Australia’s historic xenophobia' (McKnight, 134; for a more contextual discussion see especially (Dutton 2002)(Rubenstein 2002). In truth the term 'aliens' has a politico-legal context of international significance dating to the late 
eighteenth century and closely tied to the development among other things of republican thinking as well as security (Ngai 2004)(Torpey 2000). In a constitutional context the term remains alive in Australia, for example as an element of the powers of the Commonwealth government, which is enabled by Section 51 (xix) of the Constitution to make legislation with respect to 'naturalisation and aliens, ${ }^{2}$. Internationally the term 'alien’ remains the English language term of choice in migration administration: in recent times for example the Chinese immigration authorities have introduced a US-style temporary visitor’s card whose Englishlanguage translation identifies the necessary registration and control provisions to which 'aliens' shall be subject.

Third, the study of a developing policing regime for the border control and internal surveillance of immigrants provides further confirmation of the political conditions of policing, within and without national borders. As scholars of the growth of international policing co-operation have shown, the development of regimes of policing targeting criminalized activities of transnational actors (whether pirates, drug dealers or slave traders) was founded in a value politics in which criminalization represented much more than a reactive response to the identified phenomena (Andreas and Nadelmann 2006). And just as internationalization of policing operations was founded in institutional developments that required more than treaties so the elaboration of strict regimes of immigrant control at and within national borders demanded more than constitutional and legal affirmations of sovereignty and citizenship. In this context the story told below, with its narrative of police co-operation across borders, and contestation with other state agencies, mirrors the story of progress, blockages and re-engagements that characterize the growth of international policing (Andreas and Nadelmann 2006; Deflem 2002; Anderson 1989).

In what follows I seek to approach the developing and ever-changing politics of national security as involving a large number of agencies that included police, as well as intelligence agencies, defence establishments, and the departments of immigration, customs, interior and external affairs. Its focus is on police and policing strategies, but in the context of changing government policies and practices in the first two-thirds of the twentieth century. It starts from the thesis that the actions and rationales of police, at senior as well as operational levels, cannot be read as predictable from (in Weberian terms) their ideal-typical role as the agents of a state with a monopoly on the legitimate use of force, still less as agents of capital or race. That perspective informs the research on which this article is based. Acknowledging the reality of police as political actors is far from meaning that what police want is what happens, in policy or practice. In that respect this article is not just about the policing of 'the alien' but also another aspect of the politics of policing, the 
outcomes of which are never predictable and certainly never determined by a simple act of will on the part of seemingly powerful players.

\section{Aliens, immigrants and police}

In post-Federation Australia (ie post 1901) police were implicated at an early stage in the management of immigrant populations. As colonial police became the police forces of the federated States of Australia, they frequently became agents of two jurisdictions, the Commonwealth and the State in which they operated. For the purpose of administering one of the first Acts of the Commonwealth of Australia, the 1901 Immigration Restriction Act, State police were from the first empowered to arrest prohibited immigrants. In 1905 an amendment to the Act made State police into officers of the Commonwealth for the purpose of administering the notorious dictation test. ${ }^{3}$ In its application to particular populations controlled or excluded on the basis of their race, these new powers were nevertheless of a style familiar to police as part of a latenineteenth century legacy (eg in controls over Chinese, Pacific Islanders and Australian Aborigines). Moreover before 1917 the Commonwealth possessed no police force of its own. Consequently the enforcement of Commonwealth legislation (eg military service provisions enacted in 1909) generally relied on the exercise of police powers by agents who were always officers of a State police force. From these powers and functions originated the role of police in the politics of alien control.

This constitutional context was a formal condition of police powers over immigrants. A substantive development was the political context of the First World War. Once war was declared in August 1914, the loyalty of Australia's sizeable population of ‘enemy aliens' was immediately in question. In spite of initial declarations by German communities of their loyalty, Commonwealth government policy from the outset presumed their alien origins to be problematic for the future conduct of the war. As early as August 10, 1914 (a week after the declaration of war) German subjects were ordered to report their residence to their nearest police stations, a measure extended to Austrian nationals three days later (Scott, 109). In practice implementation of restrictions on aliens was slow moving, but in 1915 regulations under the War Precautions Act (1914) extended the concept of enemy alien beyond those who were not naturalised to include those British subjects of alien origin (ie those naturalised) whose loyalty was suspect. Large numbers of Germans were interned in Australia and a new politics of the (white) alien had begun (Morton 1984). In this role State police were the local agents acting under a Commonwealth mandate. The work was, in the perhaps too sanguine view of the official war historian Ernest Scott, one also of protection: 
Postprint - Finnane: ‘Controlling the alien’, published in Policing and Society19, no. 4, 2009: 442-467

In the investigation of individual cases, the intelligence section made use of the services of the local police, which were willingly given. The cool, good sense of an experienced police sergeant with a knowledge of the people living in his district, saved many a person of German origin from interference, or even from removal to a concentration camp, when reports tinged with hysteria or malice might otherwise have brought discomfort upon him.(Scott, 108)

Under constitutional defence powers and powers enacted through the War Precautions Act, the war years saw the Commonwealth deploying significant controls over population movements, within (through the obligation on aliens of residential notification) as well as into and out of Australia. In terms of policing capacity the war had other important institutional consequences. First, the absence of a Commonwealth police force was highlighted by the political conflict in 1917 between the Commonwealth and Queensland governments at a time when the national government was attempting to enact military conscription. After an egg-throwing incident at a political meeting in a Queensland country town during which the Prime Minister W M (Billy) Hughes felt that the State police had failed to protect him, the Commonwealth established its own police force(Fitzhardinge 1979, 291-296). The size and impact of the force was limited and temporary but the development signalled a longer term evolution of a Commonwealth police to complement State forces. Second, the war stimulated the development of intelligence policing, initially flowing from British imperial government initiatives exercised through the Crown's representative in Australia (the Governor-General), but closely linked to the development of the Commonwealth interest in policing. Third, the State police for the first time were exercising greater powers in defence of a national cause.

The confluence of these institutional trends was evident in a developing debate about the mechanisms of controlling aliens in the post-conflict era. The scope of the impact is evident in the agenda prepared in February 1917 for a proposed Melbourne meeting of all the State police commissioners, convened at the instance of George Steward, the Official Secretary to the Governor-General who was doubling (and trebling) as the head of the Counter Espionage Bureau and as chief liaison with British intelligence (Cain 1983). At this meeting Steward proposed to have considered the 'establishment of a uniform system' of

(a) Furnishing secret returns relating to aliens under suspicion.

(b) Dealing with crews of vessels smuggling enemy agents.

(c) Collection and examination of passports and other credentials inwards and outwards.

(d) Enquiry into antecedents of applicants for passports.

(e) Check upon traffic at seaports.

(f) Reporting movements of I.W.W. and kindred unlawful associations. 
(g) Detection of cases of Espionage. ${ }^{4}$

Wartime conditions explain the agenda for this important gathering together of all the State police commissioners, but its items spell out a range of policing roles that was to have enduring significance in the post-war world. More than that, the convening of a meeting of police commissioners revived a forum whose potential had not been realised since an initial post-Federation gathering in 1903. At that earlier gathering the commissioners had affirmed their interest in co-operation in crime fighting, especially through extradition of offenders, uniform systems for identification of criminals and cross-border co-operation. ${ }^{5}$ But at that time, even in the wake of Federation, there was little emphasis on a national dimension to their responsibilities. Thus, the agenda for the 1917 meeting was a symptom of the changes wrought by war. The very ambition of creating a 'uniform system' for the management of a range of policing duties ancillary to the requirements of national security was a stimulus to a debate within the higher echelons of Australian policing about the scope of policy and practice in the management of aliens.

This 'pre-history' of the politics of policing aliens may be concluded by noting some other outcomes of the war-time experience. First, the experience of police in their task of tracking aliens or subversive others such as members of the 'IWW [Industrial Workers of the World] and kindred unlawful associations' added considerably to their capacity to monitor political and industrial dissent and opposition in the post-war world (Cain 1983; Raymond Evans 1987; Macintyre 1998; Burgmann 1995). Second, the police became agents in this period of the practice of deportation, another security-policing capacity that would have significant longterm political repercussions, not always predictable (Fischer 1989). Third, the war-time experience of alien surveillance prompted post-war reflection on the desirability of a more consistent record of alien residence and movement in Australia.

The lack of capacity to identify aliens at the outset of war was considered in higher bureaucratic circles sufficient justification for an immediate post-war priority to extend alien registration. This was scarcely an isolated problem in the world of policing - 'at the war's start', comments Rosenberg on the French police, 'officials found themselves incapable of indentifying many enemy nationals in their midst' (Rosenberg 2006, 44), a lack of capacity they set about remedying in the inter-war years of high immigration. In England Chief Constables through the 1920s repeatedly debated their obligations to monitor the status and mobility of aliens under the country's system of alien registration, their concerns in some tension with Home Office priorities regarding the convenience of tourists and the value of free movement of business visitors. ${ }^{6}$ In Australia the problem of the invisibility of the alien was early seen as something that would require the 
instrument of policing. Preparing an agenda in 1919 for post-war legislation a senior officer in the AttorneyGeneral's Department, George Knowles, emphasised the need for two pieces of legislation, one 'dealing with naturalised subjects and aliens, with a view to the better safeguarding of national interests', the other 'providing for a closer inspection and control of immigrants which the experience of war has rendered necessary'. ${ }^{7}$ Knowles had been a member of the inter-departmental Aliens Committee of 1918 which recommended a wide range of post-war measures for the management of aliens in Australia. The Committee's recommendations were largely adopted and resulted in widescale deportations the following year (Nicholls 2007)(Fischer 1989). There were no police representatives on the Committee (which included E L Piesse, the Director of Military Intelligence) but its members were aware of the policing implications of effective alien control. Hence their recommendation that the wartime Aliens Registration provisions be made permanent including for example a contining obligation on hotelkeepers to register particulars of aliens, 'so that it is possible to compile a register and keep a record of the names and movements of all the aliens in the country'. The Aliens Committee was in no doubt that the extended use of the passport in the post-war world would 'be of immense value to the police', for example in controlling the 'possible introduction of criminals'. In these aspirations for a wide-ranging management of population at a highly individualised level, the Australian considerations were of their time. The proposed system of alien registration 'closely resembles the system at present in force in several foreign countries and for more purposes than one would be of immense benefit to the Commonwealth. ${ }^{8}$ It matched burgeoning international practice, which by this time was embracing the use of the passport and multiplying the demands for documentation of individual identity (Caplan and Torpey 2001)(Torpey 2000).

The subsequent passing of an Aliens Registration Act in 1920 signalled the desire to keep track of the communities and individuals who might be a risk to security in a future war. As the head of the fledgling intelligence agency, the Investigation Branch, put it in 1922, 'one of the outstanding lessons of the war was that some reliable knowledge of our alien community should always be available'. ${ }^{9}$ Desirable as this seemed to many in the world of policing and defence planning, the Commonwealth's proposals to continue registration fell over in the face of state government refusal to do the work unless the cost of police time was recompensed. ${ }^{10}$ By 1923 the national government had lost its capacity to identify the location of its alien immigrant populations once individuals had crossed the strictly managed borders. 


\section{Policing the alien between the wars - policing debates}

Immigration into Australia in the 1920s was not on a scale likely to prompt major questions of policing control. In this respect Australian experience was somewhat different to other societies that intensified their immigration controls at this time, prompting for example the construction by the Paris police of the largest immigration control service in the world during the inter-war years (Rosenberg 2006), or the creation of the Border Patrol of the US Immigration Service for surveillance of the Mexican border in the 1920s (Ngai 2004, 64-71) . The slow death of the alien registration system in Australia appeared to be the end of a national policy for the surveillance of immigrants, based on defence or national security demands. The decline in commitment to alien surveillance was evident at the national police commissioner conferences held annually from at least 1922 throughout the rest of the decade. The conferences were an occasion for information-sharing, and sometimes dreamy policy aspiration. In a country in which the major policing responsibilities were undertaken at a State rather than national jurisdictional level, and in which institutional frameworks for federal policy initiatives were poorly developed, the prospect of conference recommendations being taken up uniformly was limited. State jealousy of local prerogative was constantly reaffirmed by the police commissioners whenever Commonwealth aspirations to a more uniform approach to policing investigations were floated. Just such an attempt was made by the head of the Commonwealth Investigation Branch Major H E Jones at the Melbourne meeting of the police commissioners in 1923, with Jones being quickly put in his place:

Major Jones ... explained to the Conference the desire of the Commonwealth Government to arrive at some uniformity in the matter of carrying out investigations by the different Departments. After discussion it was agreed that it was a matter for the decision of the State Governments, and informed him accordingly, and not one on which the Conference of Police Commissioners could express an opinion. $^{11}$

All the same domestic policing was not divorced from larger national security questions in the early post-war years. An important test of the Commonwealth's immigration powers was provoked in 1923 by the visit of two Irish republican envoys, campaigning for Eamonn De Valera’s republican movement in opposition to the newly-established Irish Free State. Australian State police played a crucial role in keeping track of such largely unwelcome intruders and informing the responsible Commonwealth authorities of the progress of the envoys, prior to their arrest and then deportation under the Immigration Act ${ }^{12}$. More and more however police action was preoccupied with the threat of internal industrial subversion associated with radical 
industrial unionism. In 1926 the use of immigration powers as a weapon in the battle against industrial militancy failed miserably when the High Court of Australia overthrew the federal government's attempt to deport long-resident unionists Tom Walsh and Jacob Johnson (Nicholls 2007; Macintyre 1998). For the most part the police commissioners' annual gatherings appeared to see little point in debating these matters of national significance - much time was spent instead on the problem of uniform traffic rules, with challenging if unexciting problems of jurisdictional cross-recognition being discussed.

Only in 1929 were the commissioners of police prompted to consider again the possible threats arising from immigrant aliens. It seems likely that the attendance once more of Major Jones was important in shaping this agenda item. As an historian of Australian citizenship has shown, Jones was a key figure in the promotion of a pro-active policy of registration and continuing surveillance of aliens between the wars (Dutton 1998). From 1927 Jones was also Chief Officer (occasionally described more grandly as Commissioner) of the Commonwealth Police, a miniature organisation of no more than 20 men based in the new national capital ${ }^{13}$. Meeting in Perth in October 1929, the commissioners agreed that the danger of crime committed by migrants and of their involvement in seditious organisations suggested the importance of gathering pre-immigration checks on 'character' in countries of origin. The commissioners also agreed to a proposal that was farreaching in its implications - that all aliens (other than tourists) be registered by fingerprints. Both suggestions were in advance of their time, at least in the Australian administrative context, if not internationally ${ }^{14}$. The resources necessary and the commitment of the state police departments was found wanting, but above all the interruption of the Great Depression meant the shelving of such administrative ambition.

By the time the commissioners gathered in Melbourne in 1937for the first time since 1929, the emerging threat of war had helped to revive the focus on aliens and immigrants (Dutton 2002). The particular circumstances of some States, especially of Queensland, as well as changes in police leadership, provided new flavour to the discussion. Immigrants from Italy (so-called 'white aliens', whose entry was not prohibited by the White Australia Policy) had concentrated in North Queensland during the 1920s and 1930s. The close involvement of the Italian government through its Australian consular representatives, together with the increasingly antagonistic relations between fascist and anti-fascist Italian émigrés provided Queensland police with new challenges.

At the 1937 conference the Queensland Commissioner of Police, C J Carroll, brought a perspective dominated by a sense of threat arising from the congregation of non-British communities in North Queensland. Carroll (appointed in 1934 from outside the police but with impressive military experience, like 
many of the inter-war commissioners) was not the only new face among the commissioners meeting for the first time since 1929. The Victorian Chief Commissioner (responsible for extending the invitation to reconvene the conference) was Alexander Duncan, appointed from Scotland Yard and well informed about contemporary British approaches to the management of aliens. Not attending this time but an important presence in succeeding conferences was WJ MacKay, appointed Commissioner of the NSW Police in 1935 after a significant career in criminal investigation, intelligence and political surveillance (Johnston 1993)(Haldane 1996)(Cain 1986) (Richard Evans 2008). In MacKay’s place was an independent-minded superintendent who proved less enthusiastic for some of the adventurous schemes advocated by his superiors. Joining the commissioners again was Jones, described in the proceedings now as 'Chief Officer, Commonwealth Police', but bringing with him his long experience as the chief architect of Commonwealth surveillance of threats to national security in the inter-war years (Templeton 1983) (Cain 1983)(Dutton 1998). Jones was also fresh from his critical role in a 1937 inter-departmental committee on the registration of aliens. There he had advocated the re-introduction of the aliens registration statute, using the Commonwealth Electoral Offices, 'with the co-operation of this [Investigation) branch and the State Police'. ${ }^{15}$ Over the following two years he was a forceful advocate of registration.

These Canberra policy discussions were already on the minds of the police commissioners meeting in Melbourne. Queensland Commissioner Carroll confessed at the outset that he was unhappy about the Canberra considerations and had begged that committee 'to keep the matter out of the hands of politicians'. This was evidently because he regarded as unlikely the prospect of determined action by politicians to deal with the troubles created by the congregation of large numbers of Italians. Carroll told his colleagues that a third of the country’s Italian population were in Queensland and 'among them there is incessant warfare'. They were 'a lawless band... cut-throat products of the Mediterranean'. Their demands on policing were considerable, and attempts to limit their further immigration into North Queensland were hindered by 'the politician business'. Carroll thought it 'necessary also to consider the question from the angle as to whether these people are Italians or Queenslanders'. The question was rhetorical, its answer well rehearsed - 'they do not in any way absorb the ideas of this country, but remain here, inter-marry, and do not understand our laws or ordinary rules of living. They pick women up in cafes and are living on prostitution. Last year we had a murder among them unsolved - and one the year before - there is approximately one a year, 16 .

Carroll's evidence scarcely signalled a crime wave. This anti-climax prompted the Victorian Chief Commissioner's query as to the solution. When Carroll urged the adoption of an Alien Registration Act, Duncan questioned whether such a mechanism would address the problems worrying the Queensland 
Commissioner. Queensland was supported a little half-heartedly by Western Australia, largely on national security grounds in the event of war. That state also had a significant Italian ('and Jugoslav', the commissioner added) population. The South Australia Commissioner claimed that the matter had been discussed by every commissioners' conference since 1920; but he was more accurate when he cited the single occasion (1929) when a formal proposal for immigration surveillance had been adopted. From Tasmania Colonel Lord supported registration. Like Carroll of Queensland he did so on domestic policing grounds since 'we have a certain amount of trouble - knifings, shootings etc.' It was left to the NSW representative, Superintendent Lynch, to register most openly a scepticism that was seemingly shared by Duncan. 'Don't you think we are treating this as a gigantic issue when it is only an atom?' asked Lynch. 'These people are not killing us. If we are going to incur such expense in the Commonwealth and interfere with the liberty of the Italians, it will rebound on us ultimately'. ${ }^{17}$

Lynch proved to be the most original if also most ignored contributor, adding later a suggestion that police be trained to speak the languages of the people they were policing ${ }^{18}$. His interjections were against the run of play, for the meandering discussion was brought into focus by Jones. His intervention sought police support for a comprehensive registration system. The reasons were not only those of national security in its narrow frame, for Jones emphasised ancillary uses of a registration system, extending from a more systematic program of pre-migration character checking to a surveillance of settlement patterns ${ }^{19}$. In a framework that reflects debate in the upper-level bureaucratic committees of the time, Jones told the commissioners that 'we have to look at the question of alien registration from the point of view of the whole of the Commonwealth'. Registration would enable knowledge of the 'ability of a State or district within a State to absorb aliens'. Internal migration, congregation and segregation were all concerns that might be addressed through registration: 'We should know what nationalities tend to segregate themselves from the other population, thus instituting alien habits and modes of life, etc. There are hundreds of cases of migrants speaking only their own language'. Even 'morality, health and general behaviour should be noted'. In Jones' case, these rationales for an intensive domestic policing (the business generally of State police) were complemented by larger issues of national security- the threat to the country's revenue base through tax avoidance, the potential dangers of espionage, and the needs of defence planning including the need for control over 'alien clubs and meeting places'. ${ }^{20}$

The commissioners proved keen consumers of Jones’ case for a revived registration system. No concerns were raised about its costs - since he floated only the proposal that the work be carried out through the Electoral Office, unlike the earlier 1920 system which had collapsed in the face of State government 
refusal to bear the costs of their police doing the work. On their own account the commissioners added proposals that would make the registration system more finely tuned to individual recognition. Duncan suggested a photograph and a signature, important (he thought) because 'the names of some aliens, specially those of Greeks, appear to be all the same'. He wasn't the only one attending who imagined the need for greater individuation in a world of racial mixing. Attending the meeting to talk about the problems of drug traffic, the Federal Customs Collector J J Kennedy thought fingerprints were essential since 'it is very difficult to identify one Italian from another...photographs could easily be removed and others put in their places. ${ }^{21}$ If the discussion verges on a parody of Anglo-Australian chauvinism we cannot overlook the more substantive outcome - the unanimous agreement of the commissioners to support a comprehensive system of alien registration (excepting bona fide tourists), the formation of a central registry for the purpose, and the use of fingerprints and photographs on identification documents which were to be carried by 'every alien admitted to the Commonwealth'.22

Two years later, the commissioners met again on the eve of war. This time their proceedings were interrupted by a day long 'in camera’ briefing on the draft National Security Regulations, and associated consideration of the draft Code of Police War Instructions. If anything the urgency of the policing of aliens was accentuated. The atmosphere of war preparations infused the discussion - also attending and playing a prominent role in discussion were Jones, still heading the Commonwealth Investigation Branch, and Brigadier Combes, of Military Intelligence. Both men had been key players in the high-level bureaucratic development of war-time measures of domestic intelligence and security over the previous two years. Jones was unhappy with the recently enacted (but not proclaimed) Aliens Registration Act which was a 'peace-time measure'. The government had found it difficult to get this legislation through the parliament, which (according to Jones) 'was not agreeable to inflict any harsh measure of control'. The police leaders were especially unhappy that the scheme for registration was to be managed through the Electoral Registrars. Commissioner Carroll had not moderated his views on the scale of the threat coming from Italians in North Queensland. But even more persistent than Carroll was the otherwise generally more liberal NSW Police Commissioner W J MacKay, who was subsequently the first Director of the Commonwealth Security Service. Both Carroll and MacKay were much agitated over the status of women of British nationality marrying aliens, but subsequently becoming an espionage risk after successfully applying to naturalise their status. Also attending for the first time was the New Zealand Commissioner Denis Cummings. New Zealand police were pivotal to that country’s management of aliens during wartime; Cummings’s presence contributed to the conference 
recommending the adoption of the New Zealand practice of thumb-printing to be added to the Aliens Registration Form. ${ }^{23}$

Within a month of the commissioners meeting, the declaration of war with Germany ensured that the entire aliens management regime would be managed not by the electoral registrars but under the military authorities working through State police. There was no thumb-printing on the New Zealand model but registration was comprehensive and laid the basis for subsequent internment decisions. War-time conditions in northern Australia help to explain the greater intensity of internment in Queensland - but these conditions worked through human agents (Saunders 1992)(Neumann 2006). The Queensland commissioner continued to be the most forceful advocate of mandatory internment of all aliens, both 'enemy' and 'naturalised British subjects of enemy origin'. At the 1941 commissioners' conference he was much exercised by the need to reassure 'our own people' that all was being done to protect national security. He also spoke for those with anxieties over jobs and property, alleging 'that these aliens are wandering around taking these jobs as soon as the boys go to the other side'. ${ }^{24}$ His combative approach was subsequently given a fillip by the deteriorating military position, a symptom of which was the imposition of the Queensland Curfew Order on 12 February 1942, after the fall of Rabaul (in New Guinea) and a week before the Japanese bombing of Darwin. The curfew restricted all enemy aliens resident in Queensland to their own residence between the hours of 8 pm and $5 \mathrm{am}$. In spite of the easing of the direct military threat by the end of 1942, it was not until December 1944 that the curfew was reviewed, and then only for those resident south of the 'Aliens Line' (Lamidey 1947, 50-51). Carroll contributed significantly to the atmosphere of crisis through his own determination that no ground would be ceded to those who failed to share the British patrimony that he saw himself as defending. At another point after the crisis of 1942 had passed, the Queensland commissioner was adamant that the Military Order restricting possession of firearms not only by aliens but by 'naturalised British subjects of enemy origin' should not be lifted, even at a time when the Deputy Director of the Commonwealth Security Service in that State 'felt it could be revoked without any material security risk' (Lamidey 1947, 43-45).

This difference of opinion in policing leadership was highlighted during the 1941 discussions of the commissioners over the scope and means of gathering intelligence on the risk of alien activity. In contrast to Carroll's feverish determination to track down any hint of alien subversion, the NSW Police Commissioner MacKay demonstrated an approach much more sensitive to the quality of information and its context. Responding to a long-winded story from Carroll on the identification of a suspect Italian in the north Queensland town of Halifax (a story which centred on the Italian's response to the hypothetical 'Do you want Great Britain to win the war? Why?'), MacKay questioned the reliability of information coming forward from 
those who might have 'an axe to grind', a caution that he extended to the reliability of police reports. 'Some policemen are just like civilians', MacKay said. 'They get an idea into their head and it becomes a fetish with them, and they possibly have an axe to grind and they put these things up'. His preference was for independent corroboration of a suspect's loyalties through interview by somebody other than a local policeman. His dim view of local police competence for this work is partly confirmed by the scrutiny of internment files by historians of war-time Queensland, but there were also examples of more judicious use of police discretion, consistent with Ernest Scott’s judgment about the Great War ${ }^{25}$.

Three years later MacKay and his fellow commissioners had most of their wartime experience to draw on as they contemplated post-war possibilities. When they met in Adelaide in 1944, some of the personnel had changed, notably Carroll of Queensland being represented by C J Perrin. MacKay himself had for a time served the Commonwealth as first Director of its newly established Security Service. His experience there may have made him a clear-eyed advocate of policing's proper boundaries during the 1944 discussions over the future of post-war policing.

Two propositions with major implications for post-war surveillance of the population were floated at Adelaide. Conscious of the conference’s limitations as a policy-making body, MacKay initiated a discussion on the 'congregation of aliens' and the role of 'organisations having the tendency to maintain foreign national spirit to the detriment of Australian citizenship'. In spite of his hesitation, the issues were quickly wrapped into a motion put by Duncan (Victoria), seconded by MacKay. This motion noted police concern over the possibility of aliens congregating together, urging a ban on both the publication of foreign language newspapers and the formation of 'national clubs and organisations of a foreign country'. The commissioners also supported the notion that naturalisation only be granted to 'those able to speak the language of their adopted country'. But this was only the first consideration of the necessary power over aliens. Looking towards the post-war years, the conference supported a proposal that all the powers of registration of aliens contained in the National Security Regulations should be extended to peacetime, through a new Aliens Registration Act, replacing the 1939 statute which had been passed but never proclaimed. The powers would be administered through the Commonwealth Department of Interior, with the State Police Commissioners acting as 'Deputy Chief Aliens Registration Officers of the Commonwealth'. The proposals referred backwards to Australian experience (eg the necessity of the Commonwealth paying for aliens registration, in the light of the collapse of the earlier scheme of aliens registration in the 1920s); and outwards to international practice, especially of aliens control in the USA and Britain. MacKay, Duncan and the others were convinced of the peacetime necessity of aliens control. In their view, a shortcoming of the 1939 proposals had been its 
delegation of the responsibility to electoral officers - this was a power that police had won in wartime and should be continued 'in peace time too, ${ }^{26}$.

The commissioners proved more united in 1944 on the necessity of peacetime aliens registration than they were over the continuity of other wartime powers. When the South Australian commissioner proposed that the Commonwealth be urged to continue the system of 'national registration' (of all males between 18 and 65, for the purpose of manpower administration), he divided the conference. Commissioner Johns (SA) added to his powers proposal an administrative dimension for integrated security policing - the functions of the Commonwealth Security Service and of the Alien Registration Branch should be integrated and placed under the control of State Police Departments, 'who are the 'Guardians of the Peace' and upon whom all Governments rely to enforce and police their administrations'. ${ }^{27}$ The attraction of the system of registration and identity cards was its aid to general policing. As Johns saw it, 'we have had a better time since the introduction of the National Register and the Identity Card than ever before'. ${ }^{28}$

Johns’ proposal was nothing less than a comprehensive extension into peacetime of wartime powers that had already proved controversial. The more experienced commissioners were conscious of the limited political appeal of such initiatives in the Australian environment. MacKay warned that there would be 'a hue and cry of socialisation ... I think the Conference would be taking a step outside its ambit, and getting into political matters'. When Johns argued that the proposal had benefits 'from the police point of view', Duncan countered that 'we would be liable to be brought into a newspaper controversy which would be much against our interest. The public might possibly say, 'why do the police want to keep a tab on us all the time?' and they would resent it'. Perrin of Queensland agreed with Duncan that the alien registration experience suggested that identity cards were of limited value for policing purposes (eg in tracing individual law breakers); and in any case the proposal 'would conflict with ideas of the Australian people as a whole and with their interests'. The majority of commissioners in fact seemed persuaded that the war experience had tired people of 'irksome regulations' and 'regimentation'; and that to be effective such a system would be very costly. In contrast then to the desired alien controls, the proposal to track Australian citizens through a national registration system threatened police legitimacy. In the words of Commissioner Reid of the ACT police, 'it would bring the police too much into conflict with the general public'. ${ }^{29}$

In spite of their awareness that they were treading on policy ground increasingly occupied by others (especially the Immigration Department, created in 1945, and an emergent national security service), the police commissioners continued in the early post-war years to insist on discussion and advocacy of controls 
over aliens. In 1946 a discussion on naturalisation resulted in a motion that aliens be required to pass an examination in oral and written English before being naturalised. More than this, the commissioners for the most part were agreed on the necessity of controlling the publication of foreign language newspapers. The sole dissentient to this proposal was the commissioner from the largest State, NSW. More than any other commissioner MacKay was sensitive to the potentially inflammatory motion, even pushing towards a more innovative response to the pending reality of an increase in post-war migration: 'I think it is our job to learn the various languages and have on our staffs men who can read them and report what is being printed in the different papers'. His objection to a blanket ban was founded not only on a concern about embroiling police in needless controversy, but also in a more liberal approach to 'mind our own business and leave them alone to publish their papers'. The resulting motion adopted the compromise of a dual language solution to such publication for foreign language communities. ${ }^{30}$ The limited attention of the 1946 conference to the question of alien control was however a sign of police losing ownership of a domain that had largely been their own since 1939.

\section{The end of alien status? Post-war policing and the politics of immigration}

From 1945 to the mid-1960s Australian policing and security interest in aliens was sustained through the continuing reactivation of historical memories of two world wars. These were also years of a national program of mass migration which changed the Australian population in size and composition. The altered policy and social environments were constantly seen by police as major challenges to their sense of priorities. It will be recalled that the proposed registration of aliens in the 1920s was founded on the historical experience of a profound lack of knowledge of the country's immigrant population at the outset of the First World War. A different kind of memory enlivened consideration of the 'alien question' in the years after the Second World War. This was the perception that mass internment of the alien population had been too crude a weapon in the war effort, and had necessitated lengthy and bruising political and administrative remedies to address the harms caused by an insensitive policy (Saunders 1992; Bevege 1993;Saunders and Daniels 2000; Neumann 2006;Finnane 2007, 111-116). In the context of a developing Cold War, one whose demands and threats kept cutting across other government priorities it is not altogether surprising that a fledgling national security agency had constantly to wage war with other parts of the bureaucracy to defend its preference for broad-scale surveillance.

The Australian Security Intelligence Organisation (ASIO) was established in 1949 in response to British and United States pressure to address post-war intelligence leaks and concerns about Soviet spying. 
Operating without a legislative mandate until 1956, the organisation was tasked by its early 'Charters' (issued by the successive Prime Ministers Chifley and Menzies in 1949 and 1950) to protect the Commonwealth and its Territories from internal and external dangers 'which may be judged subversive of the security of Australia'. In 1950 ASIO was directed 'to establish the maximum co-operation with other agencies' in the fields of security and law enforcement (Hope 1976, App. 4A-4C). In both fields ASIO necessarily had to develop a close liaison with the State police forces, a relationship fostered from 1952 through occasional national conferences of the State police special branches, convened by ASIO.

After the brief tenure of the first Director-General of Security, Justice Geoffrey Reed, ASIO was led for the next two decades by a former military officer, Brigadier Charles Spry. Many of the critical assessments of its Director-General, Charles Spry, focus on his personal perception of the scale of national security threats, and on his alleged closeness to the Prime Minister and government of the day.(McKnight 1994; Cain 1994; Hall 1978; Aarons 2001; but see (McKnight 2008). This is understandable enough when looked at from the perspective of those who experienced the unwanted intrusion of police interest and who were all too aware of the vague and secretive conduct of the country's domestic security service. An alternative perspective might consider Charles Spry and his agency as just one element of a large governmental investment in sometimes adventurous and often costly schemes of intelligence and surveillance, whose ultimate rationale was less the mass internment of innocent civilians than the appropriate planning for management of domestic security in times of war. The administrative context of senior levels of government shows Spry advocating his departmental interests and ambitions, but also defending and adjusting the control and surveillance measures that might be both administratively feasible and politically acceptable. In this respect he was a bureaucratic and political player whose intentions and actions are more of a type with a figure like MacKay, as we have already discussed.

The creation of ASIO was far from being the only element of post-war context affecting the policing of immigrants. As the fate of proposals stemming from both Spry's ASIO and the annual conferences of police commissioners demonstrate, the policing and security agendas dealing with the management of Australia's rapidly growing immigrant populations were now in tension with a governmental approach that rejected an image of immigrants as outsiders. ${ }^{31}$ By 1958 the Minister for Immigration was deploring the connotations of the word 'alien', just as a decade before him an earlier minister had warned off the State police from any role in alien registration, not wanting to remind the country's new arrivals of the police states from which many of them had come ${ }^{32}$. Paradoxical as it may seem, during the Cold War years the discomfort of Australian political leadership with the legacies of earlier regimes of intensive and discriminatory policing 
help to explain the very real constraints on policing powers, and the failure of police to get what powers they wanted to control immigrants.

If the intensity of discussion at their leadership conferences is a guide, what the police in post-war Australia missed most about the passing of wartime conditions was the loss of the Aliens Control regulations. As we have seen, their meetings at the end of the war, and after, stressed the urgency of maintaining the kinds of comprehensive controls that had been given to them under the war-time National Security Regulations. But in 1947 the Commonwealth Government made a decisive break with the past when it mandated the establishment of a large-scale migration program that would start to undermine the policy presumption of a white and British Australia. Initiated by the first Minister for Immigration, Arthur Calwell, the policy broadened the migration intake to include significant streams of southern Europeans and of displaced persons from eastern Europe. Announcing the new direction in 1947 Calwell signalled the importance of a change that would require careful government management, both of the new intakes, and of the sensitivities of the host population. Calwell emphasised that he wanted to welcome the new settlers without the taint of a police operation to which too many of them had been subjected over the previous decade of war-time experience ${ }^{33}$.

The new order in Australian immigration policy was not lost on the police commissioners. When they met in Brisbane in August 1947 Calwell was already in Europe visiting refugee camps and making arrangements for the mass migration of displaced persons. The legislation setting the scene for now limited police responsibilities was the Aliens Act of 1947. The new approach to immigration policy had already attracted the attention of police. A new inter-state policing meeting, the Conference of Interstate Criminal Investigation Branch Superintendents (established in 1946) discussed aliens registration at its June 1947 gathering. Sponsoring the discussion was Inspector E Richards of the Commonwealth Police in Canberra who drew attention to the press reports of the minister's statements in the previous March: 'Mr Calwell said the Government believed that aliens should not be supervised by police stations because they had come from police States. They should be introduced into the Australian way of life through the Post Office or some such department'. ${ }^{34}$ True to Calwell's word, the legislation removed State police from the business of migration administration, which was now to be managed by the newly established Department of Immigration. In contrast to the oft-repeated police desire for comprehensive control of aliens in post-war Australia, the South Australian commissioner had to point out to his assembled fellows that Calwell had been explicit in the parliament: 'Aliens would be free to move at will and to take whatever employment they chose and ordinarily they would be free from police or other surveillance'. Commissioner Johns (SA) responded with a warning that 'two or three of the worst criminals in Adelaide are foreigners and I think that has been the experience in 
America'. The Australian commissioners were rendered even more depressed by their awareness that across the Tasman the New Zealand government had embraced the idea of police as alien registration agents. It was MacKay who then moved that the Commonwealth be urged to adopt the New Zealand measures 'so that aliens will be properly registered and controlled'. ${ }^{35}$ The police protests had no effect. By the time the commissioners next met, in New Zealand in December 1948, the new statute had been almost a year in force. A renewed attempt by one commissioner to urge the Commonwealth to adopt the New Zealand system of police control of aliens could not gather enough support to become a motion.

The loss of alien control did not result in the police entirely vacating the field of immigrant surveillance. But the wartime anxieties regarding the loyalty of aliens had been largely displaced by new agendas. One was the scale of the new immigration which was quickly felt in the receiving States and whose impact was registered by police administrators; a second, the over-riding policy imperative of 'assimilation'; and a third, the new security apparatus of the Cold War years. The creation of the Immigration Department produced a government agency with a very considerable policy and administration brief to manage the conditions under which immigrants would accommodate themselves to the new country. Calwell's determination that the immigrant should not encounter a police state was more than matched by the commitment of succeeding (non-Labor) Ministers for Immigration to a welcoming regime which relied less on powers of punishment and exclusion. Hence in 1952, and in spite of security and police warnings about communist threats, Liberal government Minister for Immigration Harold Holt decided that 'important considerations of principle' should not be ignored in judging whether a Greek Cypriot man should be deported because of his political activities. Those principles were liberal and legalist: the man had committed 'no breach of law for which deportation would ordinarily follow' and 'while his political activities may have been a cause of trouble and disturbance there is no evidence of a subversive intent' ${ }^{36}$

The security interest in aliens did not evaporate by any means but was only one element in a complex policing environment. A more important issue in policing during the 1950s was that of perceived threats of crime and public order seemingly posed by the presence of large populations of new settlers, many with limited or no English. Throughout the decade senior police kept up a policy campaign to address what they regarded as the incapacity of police to manage the challenges posed by the new conditions. The spectre of increase of crime was often invoked in internal police discussions, though it was only a part of the policy concern. In any case early impressions were that migrants were not excessively involved in crime. Victorian Chief Commissioner Duncan in 1950 took the trouble to estimate the incidence of 'migrant crime’ and advised his fellow commissioners that there was 'little difference between the percentage of foreign nationals 
and our own nationals who commit offences'; those from Western Australia and Queensland, who had similar analysis to call on, agreed with him. Duncan agreed that some migrants might be associated with particular kinds of violence, such as 'stabbing' which he implied was linked to 'southern Europeans', though he added a caution - 'however, I do not suppose there is much between stabbing a person with a knife and hitting him with a bottle, which is typically Australian,37.

In addition to detection of serious crime and the possible risk of its increase there were other rationales for police interest in the status of aliens and immigrants. One was the diplomatic interest of consular representatives in providing aid to an accused. In 1950 the Department of External Affairs initiated a protocol for provision of police information regarding offences by New Australians, ie immigrants; subsequently (as the NSW commissioner reported to his fellow commissioners) a form in triplicate with details of offenders of ‘foreign nationality’ appearing on a serious charge was prepared, with copies going to the Immigration Department and to Special Branch police. Other police concerns were ancillary to their general peacekeeping responsibilities and the provision of 'services' (as one CIB head very modernly put it) of police departments to communities. At the annual meeting of the CIB chiefs in Adelaide in 1950 for example, the first item dealt with the possible production of 'police booklets' in foreign languages, given the large numbers of recent immigrants, most from eastern Europe. The content of such a publication would need to address matters including road traffic law and procedures in case of accidents. The suggestion was ahead of its time - the majority present were more inclined to leave this kind of initiative to the Immigration Department and supported a motion on the importance of migrants acquiring English. A different kind of pressure on policing in the new climate came from the Immigration Department itself, which sought advice on criminal offending and status offences of immigrants. While State police departments generally responded with the information sought, there was a strong feeling among some senior police that immigration surveillance was wanting. As Inspector Ramus of the NSW CIB put it, ' if the Immigration Department ... desires authentic information in regard to convictions recorded against aliens or New Australians then they should co-operate and make it compulsory for these persons to be fingerprinted on entering Australia' ${ }^{38}$

Fingerprinting all aliens entering Australia had long been on the police agenda, but was it in the national interest in an era of high migration and commitment to 'assimilation'? Shortly after ASIO was established its Victorian regional director, Commander H C Wright, ${ }^{39}$ accompanied by the long-serving Longfield Lloyd, head of the Commonwealth Investigation Service, attended the police commissioners’ conference, meeting in Melbourne just a fortnight before the 1949 federal election that brought an end to the Chifley Labor government. The discussions, transcripts of which were circulated under confidential cover, 
were cordial. Wright spoke of the necessity of co-operation between the security agency and the State police; Lloyd wanted to ensure the best co-operation in the 'extremely confidential' business of vetting of Commonwealth public servants. But the changing agenda of Australian security policy was evident in the difficulty the commissioners had in extracting any comment from either Wright or Lloyd on the two substantive matters raised out of the police agenda. Both dealt with aliens, one the desirability of fingerprinting 'aliens and displaced persons', the other the provision of police powers to stop and check aliens for their registration papers. The Commonwealth security officials were non-committal, Lloyd eventually assuring them that he would raise the powers issue with the Immigration Department. The Commonwealth silence reflected the new reality - aliens control had already passed out of the hands of police. After their departure the commissioners continued their confidential discussions, principally around the desirability of agreement on the nature and name of the Special Branch units in each State. Most commissioners saw these units as functioning above all in response to the subversive threat of domestic communism. Only from NSW did there emerge evidence of persistent tracking of security concerns related to the new migrant groups. Commissioner Scott noted that his State's Special Branch (at this time named the Subversive Organisations Investigation Bureau) was paying attention to suspect organisations 'such as the USTACHI and SZBOR, Jugo-Slav Fascist Movement now represented in Australia'. ${ }^{40}$ The attention was percipient, but of limited significance since the security environment would be dominated in the next decade by the threat of communism rather than the possible risks associated with ethnic nationalist movements of dubious political lineage.

A final signal of the fading of a policing agenda for control of aliens was the fate of the fingerprinting proposal. As we have seen, the commissioners had long before acknowledged that no government was likely to introduce universal fingerprinting, however desirable for a range of policing reasons, many of them benign (eg the identification of dead bodies). But they persisted for some time in pressing the Commonwealth Government to adopt a general policy of fingerprinting aliens on entry to Australia. The fate of their recommendation is instructive for what it tells us about the limits on police policy influence at this time.

A month after Robert Menzies became Prime Minister in 1949 he received a letter from the Victorian Premier conveying the police commissioners' recommendation on fingerprinting of aliens and asking that it be on the agenda of the next Premiers' Conference. ASIO supported the proposal as 'undoubtedly important'; the Defence Department was agnostic though acknowledging the importance of alien control in wartime; and the meetings of an inter-departmental security committee also supported it, with the important dissent of the Immigration Department representative. It was in fact Immigration’s opposition which settled the matter, 
although formal advice back to the State Premiers had to wait almost 18 months from the time of the original letter to Menzies. The strength of the Immigration Department's case, and the authority of its policy agenda at this time, highlights not only the limits of State police power but even (though in a more complex way) that of the Commonwealth's own security agencies.

The influential Secretary of the Department of Immigration was Tasman Heyes (Markus 1996). On 3 March 1950 he set out the Department's objections to the proposal that all aliens should be fingerprinted and that State police should be given the extra power of questioning aliens. He outlined the history since 1920 of police involvement in the registration of aliens before reminding the Prime Minister's Department that in 1947 the then Minister had expressly excluded police from the operations of the new Aliens Act. Subsequently the sole responsibility for registration and control of aliens was entrusted to officers of the Immigration Department, 'whose function it is to encourage migration and the rapid assimilation of aliens into the general life of the community'. The police commissioners' proposal to enable State police, 'over whom the Commonwealth has no control', to stop and question any person they believed to be an alien might prove 'particularly embarrassing if visiting Americans, for instance, were subject to this treatment'.

As for fingerprinting aliens, Heyes drew on wartime experience to suggest that use of the vast fingerprint database had been negligible. Since the practice of fingerprinting was (otherwise than in war) limited to criminal offenders, 'the finger-printing of the non-British section of the community will be bitterly resented if the only persons fingerprinted are criminals'. The pragmatic arguments used by the police commissioners for use of fingerprints for identification purposes were a case for 'universal finger-printing' rather than being limited to the 'non-British residents of the Commonwealth'. Heyes drew attention to the potential costs of such an exercise at a time when there were already 120,000 registered aliens. Finally, alert to the appeal which the Australian commissioners had made to the New Zealand model of using police for migrant administration and the use of photographs and thumbprints, Heyes was doubtless delighted to forward to the Prime Minister's Department an extract from a letter from the New Zealand Commissioner of Police seeking information on the Australian system of alien registration. In that letter the New Zealand commissioner had alluded to 'some objections by the aliens' to the registration requirements, implying that he already doubted their utility. ${ }^{41}$ Calwell’s 1947 exclusion of the police from immigration administration seemed vindicated.

Heyes' stand was decisive. The exclusion of State police from any kind of privileged role in the regulation of migration at point of entry or after was confirmed by the new Menzies government. If aliens 
were to be subject to specialised control measures these were now to be restricted to wartime conditions, or their like. Throughout the 1950s in fact the Commonwealth's security interest in the management of an immigrant population was maintained through ASIO. Much has been made of that organisation's preparation of lists and plans for the internment of aliens (see especially (McKnight 1994, 117-122). But these were always in terms of the drafting of the Commonwealth war-book, and had as their policy context the experience of two world wars in which the status of aliens had been a controversial and muddied business. In such wartime conditions of course, State police would have their role to play. But the flavour of Commonwealth suspicion of the disposition of State police (at a minimum the lack of 'control' over them, as Heyes had alluded to above) is evident in the record of an exchange between senior government functionaries in 1951. There it was made clear that the Immigration Department's reluctance to see State police involved in the interrogation of aliens was proving a severe impediment to any considered process of file preparation for particular cases of internment. The determinedly anti-communist but liberal-minded Attorney-General John Spicer (Browne 2002) was at one with Immigration in his reluctance to seeing the State police engaged in personal questioning of aliens. But when Charles Spry indicated that he had asked Immigration whether ASIO might do the work, Spicer rebuffed the Director-General of Security: 'I like the idea of you doing it less than the idea of the State police doing it'. The Solicitor-General (Kenneth Bailey) was 'astonished' at the Immigration Department's view of the matter - but that simply pointed to how insistent that Department's position had become. In the end, with the Attorney-General determined that any internments in future would have to be on a case by case basis, and on the basis of evidence of loyalty, and with Immigration opposed to the State police doing the work, ASIO was left with the task of preparing internment files from its own resources. ${ }^{42}$ Indirectly this meant involving the State police, principally through the Special Branches. From 1952 ASIO held occasional national conferences with the Special Branches to assist the development of this national security agenda. ${ }^{43}$ But in this Cold War world, assignment (in so far as matters of national security were concerned) of the business of aliens' control to the country’s national security agency was also a symptom of the failure of State police to secure the degree of surveillance of immigrants that they had sought fitfully since the 1920 s.

\section{Conclusion}

In a settler society like Australia the history of immigration has played a key role in the construction of national security. In this respect recent criminological analysis that highlights the securitization of migration 
policy and the criminalization of the migrant as contemporary phenomena (Bosworth and Guild 2008; Pickering and Weber 2006;Weber and Bowling 2004) appears historically short-sighted. The desire to build a white British society in the antipodes was at the heart of the Federation settlement that produced the Commonwealth of Australia in 1901. The Federal Constitution empowered the national parliament to make laws for a range of areas that included immigration, citizenship and the management of 'aliens'. Absent a 'Commonwealth' police, the agents of immigration policy some four decades before the formal establishment of an Immigration Department were the police of the Australian States. Over the early decades of the twentieth century the High Court determined the scope of the immigration power in ways that affirmed its administrative character but also hedged its reach into the control of populations and individuals, subversive, alien or other. The amplification of immigration power into a mechanism of border security that also constructs national security is thus not a recent, post 9/11 or post-Tampa, phenomenon. Research into the history of Australia's treatment of immigrants and refugees as well as into the practices of internment and deportation has enriched our understanding of the depth of this apparatus of government and its articulation of a national security reasoning.

This article has explored the impact of these historical traces in the refinement of Australian policing's disposition towards migrants during the first two thirds of the twentieth century. It has been shown that 'alien' was not only a construction of legal and citizenship history but also an object of policing concern. The prominence of the 'alien problem' in the policy and practical policing agendas of Australian police leaders between the First World War and the Cold War was an effect of Commonwealth expectation that police would be indispensable to any effective management of unknown and incalculable threats in the event of increasing civil strife or of total war. But police leaders, drawing on their experience in two World Wars, expanded their vision of what policing of the alien demanded. By the early post-war years they sought universal surveillance of migrants through the still developing technologies of fingerprint and photographic databases. By this time their vision of the uses of such technologies had expanded well beyond the national security mandate that had dominated inter-war debates to include crime-fighting and victim identification possibilities. Their failure to achieve what they demanded at this time was a signal of police subordination in a politics of immigration that prioritised assimilation and integration of large new populations as a national undertaking.

The implications of this story of agenda amplification and of its dispersal in a more complex and competitive governmental environment are not confined to the historical eras which are the focus of this paper, nor to this national context. The story told here of the limits on policing and police institutions as agents of state and 
national security suggests some of the historical ground we must trace in understanding both the capacity of policing for exercise of population control and of its limits.

References

Aarons, Mark. 2001. War criminals welcome : Australia, a sanctuary for fugitive war criminals since 1945. Melbourne :: Black Inc.

Agamben, Giorgio. 1998. Homo Sacer: Sovereign Power and Bare Life. Stanford, Calif: Stanford University Press.

Anderson, Malcolm. 1989. Policing the World: Interpol and the Politics of International Police. Oxford, England: Clarendon Press.

Andreas, Peter, and Ethan Nadelmann. 2006. Policing the Globe: Criminalization and Crime Control in International. New York: Oxford University Press.

Anon. Finger-prints. QSA A/44776.

Ball, Desmond, and D. M Horner. 1998. Breaking the codes : Australia's KGB network 1944-1950. Sydney: Allen \& Unwin.

Bashford, A., and C. Strange. 2002. Asylum-seekers and national histories of detention. Australian Journal of Politics and History 48, no. 4: 509-527.

Bevege, Margaret. 1993. Behind Barbed Wire: Internment in Australia During WorldWar II. UQP studies in Australian history. St. Lucia, Qld: University of Queensland Press.

Bosworth, Mary, and Mhairi Guild. 2008. Governing Through Migration Control: Security and Citizenship in Britain. Br J Criminol 48, no. 6: 703-719.

Browne, Geoff. 2002. Spicer, Sir John Armstrong (1899 - 1978). In Australian Dictionary of Biography, 16:287-288. Melbourne: Melbourne University Press. http://www.adb.online.anu.edu.au/biogs/A160348b.htm?hilite=Spicer.

Burgmann, Verity. 1995. Revolutionary industrial unionism : the industrial workers of the world in Australia. Cambridge, UK ; New York: Cambridge University Press.

Cain, Frank. 1983. The origins of political surveillance in Australia. London ; Sydney: Angus \& Robertson.

---. 1986. MacKay, William John (1885 - 1948). In Australian Dictionary of Biography, 10:296-297. Melbourne: Melbourne University Press.

http://www.adb.online.anu.edu.au/biogs/A100289b.htm?hilite=mackay.

---. 1994. The Australian Security Intelligence Organization : an unofficial history. Cass series. Studies in intelligence. Richmond, Vic.: Spectrum Publications.

Caplan, Jane, and John C Torpey, eds. 2001. Documenting Individual Identity: The Development of State Practices in the Modern World. Princeton, N.J: Princeton University Press.

Clarke, John. 2008. Report of the inquiry into the case of Dr Mohamed Haneef. http://www.haneefcaseinquiry.gov.au/www/inquiry/haneefcaseinquiry.nsf/Page/Report.

Day, David. 1996. Contraband \& Controversy: The Customs History of Australia from 1901. Canberra: AGPS Press.

Deery, Phillip. 2005. 'Dear Mr. Brown': Migrants, Security and the Cold War. History Australia 2, no. 2: 40-1:40-12.

Deflem, Mathieu. 2002. Policing World Society: Historical Foundations of International Police. Clarendon studies in criminology. Oxford: Oxford University Press.

Dignan, Don. 1992. The internment of Italians in Queensland. In War, Internment and Mass Migration: The Italo-Australianexperience 1940-1990, ed. R J B Bosworth and Romano Ugolini, 294. Studi sull'eta contemporanea 3. Rome: Gruppo Editoriale Internazionale. 
Douzinas, Costas. 2007. Human Rights and Empire: The Political Philosophy of Cosmopolitanism. Taylor \& Francis.

Dunstall, Graeme. 1999. A Policeman's Paradise?: Policing a Stable Society, 1918-1945. Palmerston North, N.Z.: Dunmore Press in association with the Historical Branch, Dept. of Internal Affairs. Dutton, David. 1998. The Commonwealth Investigation Branch and the Political Construction of the Australian Citizenry, 1920-40. Labour History 75: 155-174.

---. 2002. One of us? : a century of Australian citizenship. Sydney: UNSW Press.

Evans, Raymond. 1987. Loyalty and disloyalty : social conflict on the Queensland homefront, 1914-18. Sydney: Allen \& Unwin.

Evans, Richard. 2008. 'A menace to this realm': The New Guard and The New South Wales Police, 1931-32. History Australia 5, no. 3: 76.1-76.20.

http://publications.epress.monash.edu/doi/abs/10.2104/ha080076.

Finnane, Mark. 2007. J V Barry: a Life. Sydney: UNSW Press.

Fischer, Gerhard. 1989. Enemy Aliens: Internment and the Homefront Experience in Australia. St. Lucia, Qld: University of Queensland Press.

Fitzgerald, John. 2007. Big White Lie: Chinese Australians in White Australia. Sydney: University of New South Wales Press.

Fitzhardinge, L F . 1979. The little digger, 1914-1952 : William Morris Hughes, a political biography, volume 2 . Sydney: Angus \& Robertson.

Haldane, Robert. 1996. Duncan, Alexander Mitchell (1888 - 1965). In Australian Dictionary of Biography, 14:49-50. Melbourne: Melbourne University Press. http://www.adb.online.anu.edu.au/biogs/A140051b.htm?hilite=duncan\%3Balexander.

Hall, Richard. 1978. The secret state : Australia's spy industry. Stanmore, N.S.W.: Cassell Australia. Hansen, Randall. 2000. Citizenship and immigration in Post-War Britain. Oxford University Press.

Hope, R M. 1976. Royal Commission on Intelligence and Security Fourth Report [re Australian Security Intelligence Organization] - Volume 2 [Appendices 4A to 4L]. File. A8908, 4B. National Archives of Australia, Canberra. http://www.aa.gov.au/cgi-bin/Search?O=I\&Number=4727807.

Johnston, W. Ross. 1993. Carroll, Cecil James (1888 - 1970). In Australian Dictionary of Biography, 13:372-373. Melbourne: Melbourne University Press.

http://www.adb.online.anu.edu.au/biogs/A130414b.htm?hilite=carroll.

Lake, Marilyn. 2008. Drawing the Global Colour Line: White Men's Countries and the Question Of. Carlton, Vic: Melbourne University Publishing.

Lamidey, Noel W. (Noel Wray). 1947. A report to the Honourable Arthur A. Calwell M.P., Minister for Immigration upon some aspects of alien control in Australia during time of war / by Noel W. Lamidey. [Canberra :: Aliens Classification and Advisory Committee], Canberra : Aliens Classification and Advisory Committee.

Macintyre, Stuart. 1998. The reds. St. Leonards: Allen \& Unwin.

Mares, Peter. 2002. Borderline: Australia's Response to Refugees and Asylum Seekers in the Wake. 2nd ed. Sydney: UNSW Press.

Markus, Andrew. 1996. Heyes, Sir Tasman Hudson Eastwood (1896 - 1980). In Australian Dictionary of Biography, 14:446-447. Melbourne: Melbourne University Press. http://www.adb.online.anu.edu.au/biogs/A140513b.htm?hilite=heyes.

Marr, David. 2003. Dark Victory. Crow's Nest, N.S.W: Allen \& Unwin.

McKnight, David. 1994. Australia's spies and their secrets. St Leonards, NSW: Allen \& Unwin.

---. 2008. Rethinking Cold War History. Labour History, no. 95: 185-196. 
Menzies, A. C. C. 1987. Review of Material Relating to the Entry of Suspected War Criminals into Australia. Canberra: Australian Govt. Publ. Service.

Morton, Richard. 1984. The Enemy within the Gates. In Australian War Memorial History Conference. Canberra: Australian War Memorial.

file://C:/Documents\%20and\%20Settings/s88758/My\%20Documents/CEPSRESEARCH/resourc es/Morton1984aliens.pdf.

Neumann, Klaus. 2004. Refuge Australia: Australia's Humanitarian Record. Sydney: UNSW Press.

---. 2006. In the interest of national security : civilian internment in Australia during World War II / Klaus Neumann. Canberra :: National Archives of Australia.

Ngai, Mae M. 2004. Impossible Subjects: Illegal Aliens and the Making of Modern America. Politics and society in twentieth-century America. Princeton, N.J: Princeton University Press.

Nicholls, Glenn. 2007. Deported : a history of forced departures from Australia. Sydney, N.S.W.: UNSW Press.

Palmer, Mick. 2005. Inquiry into the circumstances of the immigration detention of Cornelia Rau : report / Mick Palmer. Parliamentary paper / Parliament of the Commonwealth of Australia, no. 174 of 2005, http://www.minister.immi.gov.au/media_releases/media05/palmer-report.pdf.

Pickering, Sharon, and Leanne Weber, eds. 2006. Borders, Mobility and Technologies of Control. Dordrecht, Netherlands: Springer.

Priest, Susan, and Troy Simpson. 2001. Irish Envoys Case. In The Oxford companion to the High Court of Australia, ed. A. R Blackshield, Michael Coper, and George Williams, 358-359. South Melbourne, Vic.: Oxford University Press.

Rosenberg, Clifford D. 2006. Policing Paris: The Origins of Modern Immigration Control Between the Wars. Ithaca, N.Y: Cornell University Press.

Rubenstein, Kim. 2002. Australian Citizenship Law in Context. Pymont, N.S.W: Lawbook.

Ruggiero, Kristin. 2001. Fingerprinting and the Argentine plan for universal identification in the late nineteenht and early twentieth centuries. In Documenting Individual Identity: The Development of State Practices in the Modern World, ed. Jane Caplan and John C Torpey, 184-196. Princeton, N.J: Princeton University Press.

Saunders, Kay. 1992. War on the homefront : state intervention in Queensland 1938-1948. UQP studies in Australian history. St. Lucia, Qld: University of Queensland Press.

Saunders, Kay, and Roger Daniels. 2000. Alien justice : wartime internment in Australia and North America. St Lucia, Qld.: University of Queensland Press.

Scott, Ernest. Australia during the war: Official History of Australia in the War of 1914-18 Vol 11. file://C:/Documents\%20and\%20Settings/s88758/My\%20Documents/CEPSRESEARCH/resourc es/ScottEnemyVolXI.pdf.

Templeton, Jacqueline. 1983. Jones, Harold Edward (1878 - 1965). In Australian Dictionary of Biography, 9:512-513. Melbourne: Melbourne University Press. http://www.adb.online.anu.edu.au/biogs/A090508b.htm.

Thomas, Martin. 2008. Empires of Intelligence: Security Services and Colonial Disorder After 1914. Berkeley: University of California Press.

Torpey, John C. 2000. The Invention of the Passport: Surveillance, Citizenship, and the State. Cambridge studies in law and society. Cambridge [England]: Cambridge University Press.

Weber, Leanne, and Benjamin Bowling. 2004. Policing Migration: A Framework for Investigating the Regulation of Global Mobility. Policing and Society 14, no. 3: 195. doi:10.1080/1043946042000241802.

http://www.informaworld.com.libraryproxy.griffith.edu.au/10.1080/1043946042000241802. 
Postprint - Finnane: 'Controlling the alien’, published in Policing and Society19, no. 4, 2009: 442-467

${ }^{1}$ Australian historical accounts that respect these changes include (Bashford and Strange 2002; Neumann 2004;Nicholls 2007). For an exemplary study in United States history see (Ngai 2004).

${ }^{2}$ For a recent Australian High Court discussion of the scope and history of the power see Singh v Commonwealth [2004] HCA 43 (9 September 2004) http://www.austlii.edu.au/cgi-bin/sinodisp/au/cases/cth/HCA/2004/43.html: Gummow, Hayne and Heydon JJ, (par.163) citing Quick and Garran, The Annotated Constitution of the Australian Commonwealth, (1901) at 599 ‘In English law an alien may be variously defined as a person who owes allegiance to a foreign State, who is born out of the jurisdiction of the Queen, or who is not a British subject. The rule of the common law is that every person born out of the British Dominions is an alien, and that every person born within British Dominions is a British subject. This is known as the jus soli or the territorial test of nationality, which is contrasted with the jus sanguinis or the parentage test of nationality.'

${ }^{3}$ See Immigration Restriction Amendment Act 1905; as explained by the Prime Minister Alfred Deakin, the amendment was necessary 'because the Commonwealth officers are stationed on the sea-board, and when a prohibited immigrant manages to reach the interior an officer has to be despatched from the sea-board to apply the education test. The proposed amendment will enable any policeman who may be on the spot to administer the test.' (Commonwealth Parl Debates, v 28 1905: 4922); see also (Nicholls 2007, $31)$.

${ }^{4}$ Steward to Secretary, Prime Minister’s Department, 13 Feb 1917, National Archives of Australia (NAA), A2939 (A2939/1), SC245, Conference - Police Commissioners. No transcript or record of this conference has survived on file.

5 'Report of Police Conference held at Melbourne [22 Oct 1903]' in 'Finger-prints', Queensland State Archives (QSA) A/44776 .

${ }^{6}$ Eg Minutes of Deputation of Chief Constable to Home Office re Alien Registration, 30 Oct 1923, in Association of Chief Police Officers Archives (Open University, Milton Keynes), Bag 65 - 'Preliminary Meeting - Central Conference of Chief Constables 1921- 1938'.

${ }^{7}$ Knowles minute (nd, 1919), Aliens Registration Bill 1938, A432 (A432/85), 1938/916, NAA.

${ }^{8}$ Report of the Aliens Committee, 1918, para. 23: Aliens Committee (Australian) Correspondence with States arising from Report of Committee, A2 (A2/1), 1919/1780, NAA.

${ }^{9}$ H E Jones to Secretary AGs Dept, 24 Jun 1922, ‘Aliens Registration Bill 1938’, A432 (A432/85), 1938/916, NAA.

${ }^{10}$ Cabinet memo, 14 April 1938, Aliens Registration Bill 1938, A432 (A432/85), 1938/916, NAA. The 1920 Act was suspended in 1926 and repealed in 1934. 
${ }^{11}$ Proceedings of Annual Conference of Commissioners of Police (hereafter CPC) 1923-1936, p. 4 (Melbourne 13 Mar 1923) (courtesy of Victorian Police and Australian Commissioners of Police).

${ }^{12}$ See (Priest and Simpson 2001;Dutton 2002). The case has not been well understood in the literature, especially with respect to the position of the envoys as hostile agents of an armed opposition to the newly formed Free State. The role of State police in surveillance of the envoys is well illustrated in the relevant archival files held in the National Archives of Australia and the State Archives of NSW.

${ }^{13}$ For the development of the police function in the Australian Capital Territory see the agency note (CA665) at NAA.

${ }^{14}$ For example, the Immigration Department in Argentina established a fingerprint register for identification of immigrants in 1912 (Ruggiero 2001, 191-2)

${ }^{15}$ Jones memo, c. 1 Sep 1937, [Alien migration policy], NAA A373 (A373/1), 3075.

${ }^{16}$ Carroll, 1937 CPC, p. 3 ('inter-marry’: Carroll presumably meant they married within their own community).

${ }^{17}$ CPC 1937, pp. 3-5.

${ }^{18}$ In fact lessons in Italian were being conducted for Queensland police at this time.

${ }^{19}$ There was already a significant number of inquiries into settlement (and 'absorption') patterns of 'white aliens', associated with controversy over the impact of European migration: (Dutton 2002, 95-6); Garrett (Interior) to Jones (IB) 8 Jul 1938, [Alien migration policy], A373 (A373/1), 3075, NAA.

${ }^{20}$ CPC 1937, p. 7.

${ }^{21}$ J J Kennedy was later Comptroller-General of Customs (1946-1949): (Day 1996).

${ }^{22}$ CPC 1937, p. 9.

${ }^{23}$ From July 1938 the New Zealand Police were already assigned the responsibility for aliens control: (Dunstall 1999, 314-321).

${ }^{24}$ CPC, 1941, (Nov.), pp. 58-60.

${ }^{25}$ CPC 1941, p. 59. See eg (Saunders 1992, 28;Dignan 1992).

${ }^{26}$ CPC, 1944, pp. 40-42.

${ }^{27}$ Ibid, 54.

${ }^{28}$ CPC, 1944, pp. 54-55.

${ }^{29}$ CPC, 1944, pp. 51-58.

${ }^{30}$ CPC, 1946, pp. 4-7. 
Postprint - Finnane: 'Controlling the alien’, published in Policing and Society19, no. 4, 2009: 442-467

${ }^{31}$ Similar reworking of the role of police in relation to aliens arose in Britain during the 1950s, leading both to the revision in the late 1950s (for the first time since 1934) of the 'Police Handbook on Aliens', and proposals shortly after by an Inter-Departmental Committee for a winding back of police responsibilities for alien registration. The accelerating concern about rising immigration from Commonwealth and colonial countries was an important British context for a reconfiguration of bureaucratic responsibilities, with police increasingly seen as redundant in the wake of the expanding role of the Immigration Service. A reflection of these transitions is evident in the annual Central Conference of Chief Constables during the 1950s: Bag 88, 'Preliminary Meetings of the Central Conference', ACPO Archives (Open University, Milton Keynes); on the larger political and policy context see (Hansen 2000).

${ }^{32}$ Downer 2nd Reading Speech on Aliens Bill 1959, abolishing certificates of registration, 9 April 1959 in A6122/47, 1871, NAA; Calwell, $2^{\text {nd }}$ R speech 1947 Aliens Act, A446/156, 1967/70458, NAA.

${ }^{33}$ Calwell, $2^{\text {nd }}$ R speech 1947 Aliens Act, A446/156, 1967/70458, NAA.

${ }^{34}$ Conference of Interstate Criminal Investigation Branch Superintendents, Brisbane, 1947, p. 25.

${ }^{35}$ CPC, 1947, p. 13.

${ }^{36}$ (Deery 2005); and see Minute of Harold Holt, Minister for Immigration, 19 Dec 1952, Anastassiou Demetris - part 1, A6980, S200624, p. 12, NAA.

${ }^{37}$ CPC, 1950, pp. 40-41.

${ }^{38}$ CIB, 1950, p. 7.

${ }^{39}$ For ASIO’s early appointments and structure see (Ball and Horner 1998, 294-300).

40 ‘Police Commissioners' Conference - Melbourne - November 1949’ NAA A9108 (A9108/3), Roll 14/19, p. 8. See (McKnight 1994) for the longer-term security interest in these groups, which became a major concern in the 1960s and early 1970s.

${ }^{41}$ Heyes (Immigration) to Secretary, PM’s Dept, 3 March 1950, in 'Control of aliens - Conference of Police Commissioners 1949', NAA A462 (A462/8), 210/2/6. The scale of the exercise was no idle matter - by 1958 there were a 'million [registration] cards in Sydney and Melbourne alone' and Heyes was pressing for the registration provisions to be wound back: Heyes (Immigration) to Spry (D-G, ASIO), 7 Jul 1958 enclosing draft of letter to Prime Minister, in 'Law - Commonwealth registration of aliens in Australia - repeal of Aliens Act - ASIO file - Volume 1 [175p]’, A6122 (A6122/47), 1870, NAA.

42 'Memorandum of conference in Melbourne 14 Sep 1951 (Spicer, Bailey, Spry) - Detention Aliens Australian Internment Policy Excluding Stateless People', A6122 (A6122/46), 1784, NAA. My interpretation of this event thus differs in some respects from the 
Postprint - Finnane: 'Controlling the alien’, published in Policing and Society19, no. 4, 2009: 442-467

account given in (McKnight 1994, 119). Tensions between ASIO and Immigration were evident in other domains such as the security vetting of prospective immigrants - see generally (Menzies 1987).

${ }^{43}$ ASIO briefing, 'Detention in Wartime of Persons' set out the policy and the expectations of Special Branch to keep informed of the locations of people on the lists prepared by ASIO: Conferences at HQ ASIO with Police Special Branch Officers $4-8$ February 1952, A6122 (2004/00095196), 2162, NAA. 